\title{
The situation of lyrical literature in the sixth century
}

\section{La situación de la literatura lírica en el siglo VI}

\section{Mostafa Asadi}

PhD Student in Persian Language and Literature, Islamic Azad University, Mashhad Branch, Iran

\section{Reza Ashrafzadeh}

Member of the Department of Persian Language and Literature, Islamic Azad University, Mashhad Branch, Iran

\section{Mahmoud Mahdavi Damghani}

Member of the Department of Persian Language and Literature, Islamic Azad University, Mashhad Branch, Iran

*Correspondence

Email: RezaAshrafzadeh@gmail.com
Cite as:

Asadi, M., Ashrafzadeh, R., \& Mahdavi Damghani, M (2021). The situation of lyrical literature in the sixth century Propósitos y Representaciones, 9(SPE2), e997. Doi http://dx.doi.org/10.20511/pyr2021.v9nSPE2.997 


\section{Summary}

The sixth century is the Seljuk period from exciting times to different centuries in Iran. This study analyzes the causes and factors of changes in the style of poetry and its content and themes and changes the sponsors of poetry and finding poetry among the common people Mysticism and Sufism have dealt with the needs of the troubled society of that century. In this study, due to the tendency of the monasteries towards the monasteries in the sixth century and the lack of attention of the Seljuk kings to the poets, there was a lack of introspection of the poet and interesting mystical agreements in his view and attention.

Keywords: Seljuks, Lyrical literature, Sixth century, Praise poems, Mystical lyric poems, Satire

\section{Resumen}

El siglo VI es el período Seljuk desde tiempos emocionantes hasta diferentes siglos en Irán. Este estudio analiza las causas y factores de los cambios en el estilo de la poesía y su contenido y temas y cambia los patrocinadores de la poesía y encuentra la poesía entre la gente común El misticismo y el sufismo se han ocupado de las necesidades de la convulsa sociedad de ese siglo. En este estudio, debido a la tendencia de los monasterios hacia los monasterios en el siglo VI y la falta de atención de los reyes selyúcidas a los poetas, hubo una falta de introspección del poeta e interesantes acuerdos místicos en su mirada y atención.

Palabras clave: Seljuks, Literatura lírica, Siglo VI, Poemas de alabanza, Poemas líricos místicos, Sátira

\section{Introduction}

Despite the great anxiety in the situation of the sixth century society from the fall of Ghaznavid rule in Khorasan and Iranian governments in Iraq, Persia, Gorgan, etc. and the coming to power of the most important Turkish, Seljuk and Turkish elements and the impact on the process of poetry and religious and religious fanatics and religious and religious fanatics. Naturally, these currents were affected, changes were made, and poems and poems of praise flourished, and the market for mystical lyric poems flourished in that turbulent and unstable society. Beth and the glory of hard pleas from the people of the society reaches its peak. These issues are all reminiscent of the difficult period of foreign domination in the vast land of Iran in the minds of the people, which led to the change of Khorasani style to Iraqi and turned Khorasani style extrovert poetry into an introverted Iraqi style poet. Which is the cause of all changes in the rulers of the time and political, social and sometimes geographical situations that this study has been studied analytically, library.

\section{Research background}

The present study deals with the causes and emergence of lyrical literature in the sixth century and the causes and factors in changing the format and content of poetry, but this article was not found. With the titles of Critique and Review of Theories of Lyrical Literature, they have extensively recorded that the present article has only limited to lyrical literature and its developments in the sixth century. 


\section{Statement of the problem}

The motive for the tendency of the subject of lyrical literature in the sixth century and the expression of the causes and factors of poets turning to different types of lyricism is one of the reasons for choosing the subject of research and receiving the causes and factors of changes in the style and content of poetry in the sixth century. Forgive to look at the changes with a keen eye, the Khorasani-style extrovert poet who has become an Iraqi-style introvert poet through the political and social maze of the sixth century society and examine the effects and factors of these changes.

\section{Research Hypotheses}

- What is the status of the style of poetry in the sixth century?

- What is the status of court poetry and mystical poetry in the sixth century?

- What is the role of poets in the development of lyrical literature in the sixth century ?

- Why did the extrovert poets of Persian literature turn to introversion in the sixth century

Ghana in the word means hymn, song and melodious song. Poetry is a poem that reports the emotions and feelings of the poet. The gentle spirit of the poet in the creation of lyrical literature, which is a valuable form of Persian literature, expresses the deep human feelings through soft and gentle language using deep and emotional meanings. Its lyrical collection, as its name suggests, are poems to express deep human feelings, loves, pains, hardships, frustrations, and what affects the human soul. The sixth is the poems and poems of Nezami Nezami, the poems of Sanai, Khaghani of the type of lyrical literature. The lyrical poem indicates the inner states and melodies of the poets, which is the most delicate and valuable type of poetry in Persian literature. And romantically, the preposition and the combination of the middle and the quatrain and the duplicity and other forms of poetry have been expressed. Nai, who is the founder of mystical terms in Persian poetry, in addition to expressing love and passion and stories of connection and separation in festive love stories, mystical mature thoughts that originate from great poetic influences and emotions, and later in the poetry of poets like Attar This window on success in the half-hearted body of Persian literature revived it and brought a new look to the minds of poets and changed the face of Persian literature. The foundation of the greatness of Persian literature in It is the sixth century that if this had not happened, in these turbulent and tragic centuries of the sixth and seventh centuries, the situation of Persian poetry would have been badly awaited.

For this reason, the period from the fifth to the end of the seventh century is called a very important and valuable period in the creation of important works of Persian literature. The result of these periods is the birth of deep mystical and romantic thoughts in all themes in Hafez's prodigy thoughts. Has not seen e.

The basis of sociological notions of a literary work is its value to the social contexts of its emergence and the effects that the work receives from its environment as a collective phenomenon. Consumption is very important in how a literary work develops, because a literary work is the achievement of the society in which it was born and naturally inherited traits from its producer and homeland, given the meaning that society is in the structure of the poet's thoughts. It plays a very important role and makes the poet's thoughts and ideas the social factors that govern society. The poet, as an element of the society in which he lives, needs the approval of a group of like-minded people to approve his poetic art. However, society also 
supports the poet. Tries to be compatible with the actions and beliefs of that environment. (R, K, Mehraban, 2008: 9-10)

The environment also confirms a poet who has grown up in his time and according to the existing factors of that society, that such a poet whose thoughts and ideas are in the thoughts and ideas of his society and the approval of the society is drawn on his thoughts. He goes beyond land and time and finds eternal life.

"There is an inevitable solidarity between the poet-artist and society," says Durkheim, "because the origin of the most individual art is always its most collective form, and the origin never emerges except the collective. Therefore, this view is that artists are not isolated from their society." In fact, it is the society that, with its support and providing the grounds for growth and excellence, gives them the opportunity to be fertile and be introduced in the society.

Poets, as a sensitive group, deal with social, political, cultural and religious creations in order to easily provide the ground for lyrical literature by expressing their inner feelings and emotions, which is the beginning of the prosperity of expressing mystical feelings and connection with the deity of their existence. His eternal lover was founded in the sixth century, which is a very valuable turning point in Persian literature.

The collective tendency of poets to mystical issues and lyrical literature changed the society's attitude towards poetry and opened a new cultural and artistic attitude in Persian literature. Lucien Goldman believes that true cultural creation is not possible unless its mental structure matches the mental structure of a group whose goal is to organize life. Social is in the direction of progress "(Goldman, 1997: 28). This rise to mystical issues in Sana'i poetry and nobility led the organization of social life to greater hobby.

The relationship between the Seljuk government and the change of poetic themes in the sixth century, after the Samanid and Ghaznavid periods, the Seljuk era has arrived. Although the previous two periods were supporters of courtiers' poetry, but in the Seljuk era the government due to unrestricted openings and huge costs of wars Many who "in the history of Islam as the beginning of a new period in the history of Iran, the Islamic world, which at the beginning of the domination of this people, the caliphate has weakened" (Mehraban, 1387: 20) the government can not pay prayers in the style of previous dynasties In the Seljuk government, although the ode of praise has not yet lost its prosperity, it does not have the excitement of the previous era. The lyric poems seen in the fourth and fifth centuries are a kind of very motivating lyrical poems. Is.

Ghazals in the fifth and sixth centuries, although they contain simple, heartwarming and romantic meanings, but they are not empty of harsh words and expressions for the ode, the ghazals are very short and the poet's name is not mentioned at the end of the ghazal. Gradually, the poet's relationship with Barbarum faded and a deep gap was created between poetry and poetry, which was drawn to the monastery on the whole path of poetry and poetry. In the Seljuk period, oppression and aggression, people's views led to superstitions and sometimes religious beliefs that originated every nerve and thought. They connect the divine infinity and consider themselves compelled to accept it, and the Seljuk government, using the same ideas, chooses religious prejudice instead of religious freedom.

"In the unsettled state of society and the deplorable conditions in which everyone was in a position to save their lives, whether or not moral virtues were forgotten and obscenity and lying 
became commonplace, people often died instead of forming a single line against a common enemy. They fell on each other in the hope of immediate benefit, and the brothers and compatriots and men of the country were handed over to the bloodthirsty enemy with baseless accusations. "(Ravandi, 1985, vol. 5, 129)

With such a situation that prevailed in the society, the situation of poetry does not remain unaffected. The most important issues in Persian poetry of this period are the extreme pessimism of poets in poetry. People are looking for a safe place to create peace, society has lost trust in everything. Insecurity in society and chaos is one of the things that affect society.

"The era of Mansour Hallaj can be mentioned as an example. The corruption of the Abbasi family has taken place well and the hopes that in Iran have been replaced by the violence of the era due to the transfer of the Mamun period. It is obvious that someone like Hallaj, when he sees that religion has gone so far from his path, it is not surprising that he draws the pen of invalidity of all the rules of the world, when in Islam itself various sects appear and draw swords on each other, Mansour To step on all divisions, to call all the people of the world brothers and members of one family.

The Hallaj movement, like Siavash and Christ and Socrates, had a political aspect and was a protest against the centers of power of the time that were entrenched in religion and government. (Masinos, 1393, quoted by Arsafa, 1391, vol. 1, 361) Who invite their suffocating society to consciousness, a society that is in gearThe politics of the state are being destroyed and men are trampling on the power-seeking of their rulers. These inconsistent ideas are a direct result of the distress of the social situation of the day, which leads to the emergence of opposition literature. The period fosters the emerging Turkish slavery. And he would ride on the shoulders of the people in order to maintain their wealth and their lives and make them subject to their own desires. Every few years, every city would fall into the hands of an emperor who claimed dominance, but it was not long before another invaded it and the looting market became popular for a while.

The women and children of the people were taken into captivity, their property was plundered. It was reflected. (R, K, Safa, 1391, J 2: 368-361) The reflection of pessimistic thoughts and despair in society leads to the escape of poets from the outside world and the tendency to the inner world and causes the poetry and poet to deal with the situation in society.

"After the disillusionment with Umayyad and Abbasid Islam, and then the ominous works of the Arab-Turkish alliance, and the result is the trampling of the deprived class and the suffocation of enlightened and vibrant people, this state of mind reaches its peak in the Mongol conquest. Poets because of these political, social and insecure factors Lately, in the last years of their lives, they desire i'tikaaf, seeking their peace in the privacy of their god, a solitude in which there is no longer a religious color, according to Bertrand Russell. "It is a heresy brought by the prophets of the Children of Israel" (History of Western Philosophy, Russell, translated by Najaf Daryabandari, p. 595, vol. 2, Ravandi) "Otherwise, according to the Iranian mystics, the path to ... It is the people "(Ravandi, 1997: vol. 2, 564) and the heartache can be found a way to God. According to Brockman, one of the reasons for the spread of Sufism was In order to escape such controversies, Weslim used the method of Sirusluk, who considered himself superior. They put religious and political rhetoric. (Brockelman, 2005: 203, quoted by Ravandi, 1997, vol. 2, 564) 
The troubled day of society, the poet does not create much joy, his feelings are wounded and his soul is weak, he seeks to find the way to true love, he is frustrated with another day, he never seeks material things. To find.

The mystic poet seeks his liberation in mysticism and has become a supporter of the poets to the ruling court, because the mystics sought to discover freedom from the material constraints of life. A way to save others from the abyss of destruction and to respect the rights of others. "I disagree with what you are saying, but I am willing to sacrifice my life so that you have the right to do it," said the great French thinker to show the status and value of freedom of speech and thought.

The existential value of individuals and their attitudes play a role in the society in which they live. "Society can be an effective factor in all aspects of the existence of poetry and the poet's thoughts. Because no poet is valuable in a society without educated and artistic people." The creator of a work of art belongs to a certain country and a certain social class and social groups in society, each of which has collective manifestations and customs and traditions, which with all the weight of the tradition of the artist's shoulders. Rather, the inspiration that erupts in an external form The social environment is flowing. "(Mehraban, 1387, 18)

Reasons for the popularity of lyrical poetry of the sixth century and the increase in the number of poets

The Persian language and literature developed remarkably during this period. The rich were a great tool for increasing the number of poets and writers. And this was the breeding ground for more poets and writers of the period than before.

Inside Iran, in addition to the East, other regions, such as Ajam Iraq and Azerbaijan, became important centers of Persian literature. It continued and with this, several books appeared in Persian language and with the penetration of monasteries' poetry in this period, all mystical books and Sufi systems were written in simple and understandable language to guide the people. These issues were changed in the forms and themes of poetry. (See, Safa, 2012, 326-325)

In the Samanid and Ghaznavid eras, he was famous for his patriarchal poetry. Less and generally not in the dance market during this periodDozens of praises in the heat of the previous period and not relatively expensive prayers were used in the past. Poets gathered everywhere in Iran where the newcomer of the Turks rose up to receive great prayers and in the end they began to condemn poetry and poetry in vain and frustrated. (See: Mehraban, 1387: 257) and the view of poets in my poetry was slightly changed and the background for the emergence of other types of lyrical literature in my poetry was introduced to me.

The government of the men at this time had nothing to do with the consolidation of their power from the time of their political suicides. The period of eulogy gradually lost its color and "with the growth of Sufism and the influence of religious thought among the people, monasteries spread The course deals with topics such as the glory of the instability of the time and asceticism, sermons, teachings and mystical teachings.

Naser Khosrowmi says:

"I said what a bribe it was and what I got from their property and wealth

From Shah Zai Faqih, as it were, we went to Kezbim and became a dragon. " 
(Naser Khosrow, 1364: 273)

Vesnaei creates the expression of mystical terms in poetry and becomes an example for later poets and leads poets towards religion and mysticism. They spend their poetry on deep mystical thought.

The sixth century should have a turning point in Persian literature. Poetry from this century goes from earth to heaven. The rulers are not happy with their society and each of them is busy composing a poem in some way. Nezami is creating love stories. Poetry accelerates and creators create a lot of power. The prevailing atmosphere in society and the kind of literature of opposition and knotted fists increase the ground for strengthening the poetic foundation of poets. Under its shadow.

Mystic poets and lovers of love, each of whom deals with the path of divine manifestations in a way. Such factors have changed the style and variety of the subject, which has increased the importance of lyrical literature in this century. It changed because the center of the changed poetry and Khorasani words no longer shines on the poems and the content of the poem that was taken from the court could not be an ode, but the prosperity of the sonnet increases and the poets tend to this format more than other types.

\section{Result}

As a result of this study, it should be noted that in the sixth century, when the rulers of the country followed the losses and shortcomings that occurred in their governance and the departure of poets from the court due to the negligence of kings and rulers of the time, the extrovert poets of Persian literature gradually They tended to be oriented and took refuge in the heart full of pain from the court. Khaneghah was a safe place to cultivate mystical spirit and far from the noise of the exterior. .

The main form of poetry was sung on the eve of the Iraqi style approach so that poets could better express their goals. In mysticism, this background introduces great poets such as Rumi, Saadi and Hafiz. The evolution of mystical literature has passed and the practice has become very useful for others after it. He rides to return to his origin and to fulfill the purpose of his creation and to spend his solitude with his God, he does not like the form and content of praising the power of people's thinking.

References:

Ravandi, Morteza: (1997), Social History of Iran, Volume 2, Tehran, Ferdows Publishing (1997), Social History of Iran, Volume 9, Tehran, Ferdows Publishing (1997) Social History of Iran, Volume 5, First Edition of Calcutta

Safa, Zabih A., (2012), History of Iranian Literature, Vol. 1, Tehran, Ferdows Publishing Safa, Zabih A ... (2012), History of Iranian Literature, Vol. 2, Tehran, Ferdows Publishing Safa, Zabih A ... (2012), History of Iranian Literature, Volume 5, Tehran, Ferdows Publishing Goldman-Lucin, (1997), Society, Culture and Literature, translated by Mohammad Jafar Pooyandeh, Tehran, Cheshmeh Publishing 
Mehraban, Javad, (2008), Sociology of Persian Poetry, Vol. 1, Ch. 1, Tabaran Publishing

Naser Khosrow, Abu Moein Hamid al-Din, (1364), Poetry Divan, biography by Taghizadeh, edited by Mojtaba Minavi, comments by Ali Akbardokhoda, Tehran, Book World. 